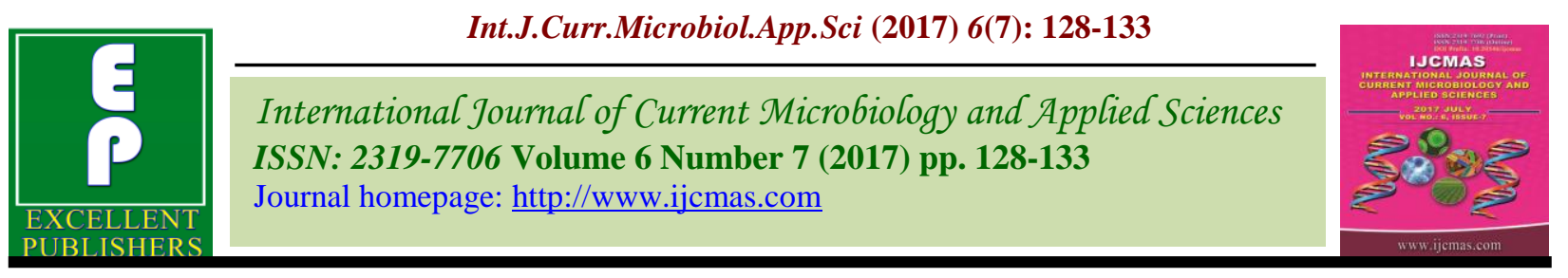

Original Research Article

https://doi.org/10.20546/ijcmas.2017.607.015

\title{
Effect of Poultry Manure and PSB Culture in Conjunction with Different Levels of Phosphorus on Physico-Chemical Properties of Soil of Black Gram (Vigna mungo L.)
}

\author{
Raisen Pal*, N. Swaroop, Arun A. David and T. Thomas \\ Department of Soil Science and Agricultural Chemistry, Sam Higginbottom University of \\ Agriculture, Technology and Sciences- 211007 Allahabad, U.P., India \\ *Corresponding author
}

\begin{abstract}
Keywords
Black gram,

Poultry manure,

PSB, Phosphorus

and soil properties.

Article Info

Accepted:

04 June 2017

Available Online:

10 July 2017 Institute, Allahabad. By order to evaluate the effect of different treatment of poultry manure and PSB culture with levels of phosphorus. The Soil parameters viz. bulk density $\left(\mathrm{Mg} \mathrm{m}^{-3}\right)$, particle density $\left(\mathrm{Mg} \mathrm{m}^{-3}\right)$, Pore space $(\%)$ and water holding capacity (\%), $\mathrm{pH}$, $\mathrm{EC}\left(\mathrm{dSm}^{-1}\right)$, organic carbon $(\%)$, available nitrogen $\left(\mathrm{kg} \mathrm{ha}^{-1}\right)$, phosphorus $\left(\mathrm{kg} \mathrm{ha}^{-1}\right)$ and potassium $\left(\mathrm{kg} \mathrm{ha}^{-1}\right)$. All parameters of soil properties are found significant accept Pore space (\%). Physical properties viz., Bulk density $\left(\mathrm{Mg} \mathrm{m}^{-3}\right)$, Particle density $\left(\mathrm{Mg} \mathrm{m}^{-3}\right)$, and Water holding capacity (\%) was recorded as $1.30,2.85,52.94,64.69$. chemical properties viz., $\mathrm{pH}, \mathrm{EC}$, organic carbon (\%), available nitrogen $\left(\mathrm{kg} \mathrm{ha}^{-1}\right)$, available phosphorus $\left(\mathrm{kg} \mathrm{ha}^{-1}\right)$ and potassium $\left(\mathrm{kg} \mathrm{ha}^{-1}\right)$ was recorded as $7.19,0.19,0.79,263.01,23.89,132.57$ respectively in the treatment was significantly higher as compared to other treatment combination. Bulk density $\left(\mathrm{Mg} \mathrm{m}^{-3}\right)$, particle density $\left(\mathrm{Mg} \mathrm{m}^{-3}\right)$ Pore space $(\%)$, water holding capacity $(\%)$, organic carbon $(\%)$, available nitrogen $\left(\mathrm{kg} \mathrm{ha}^{-1}\right)$, and potassium $(\mathrm{kg}$ $\left.\mathrm{ha}^{-1}\right) \mathrm{T}_{8}(\mathrm{P} 100 \%+$ poultry manure $)$ and $\mathrm{pH}, \mathrm{EC}\left(\mathrm{dSm}^{-1}\right)$ and available phosphorus $\left(\mathrm{kg} \mathrm{ha}^{-1}\right)$ $\mathrm{T}_{9}$ [P $100 \%$ + PSB culture] was found to be the best, for improvement of the physicochemical properties of soil.
\end{abstract}

\section{A B S T R A C T}

The experiment was conducted during kharif (July-October) season 2016 on crop research farm of Department of Soil Science and Agricultural Chemistry, Naini Agricultural

\section{Introduction}

Black gram (Vigna mungo L.) is one of the most important pulse crop grown in India. Black gram contributes $13 \%$ in total pulse area and $10 \%$ in total pulses production of India. Black gram seeds are highly nutritious containing higher amount of protein (24-26\%) and are reported to be rich in potassium, phosphorus and calcium with good amount of sodium. It is also reported to be rich in vitamin $\mathrm{A}, \mathrm{B}_{1}, \mathrm{~B}_{3}$ besides nutritionally rich protein, important minerals and vitamin (Selvakumar et al., 2012).
Proper fertilization is essential to improve the productivity of black gram. It can meet nitrogen requirements by symbiotic fixation of atmospheric nitrogen. The nutrients which need attention are phosphorus and sulphur (Mir et al., 2013). Levels of phosphorus are the most important factors affecting the yield of black gram (Madan Ananda Jagannath et al., 2014) Phosphate solubilizing microorganism used for treatment of seed or soil. They are organic products containing living cells of different types of 
microorganisms, which have the ability to convert nutritionally important element from unavailable to available form through biological process. The PSB like Pseudomonas and Bacillus also enhance the availability of phosphorus to plant by converting insoluble phosphorus from the soil into soluble form (Swati kadam et al., 2014).

Soil fertility cannot be maintained with the application of inorganic fertilizer alone. No single source can meet the increasing nutrient demands for agriculture, to achieve sustainability in production, there is a need to integrate both organic and inorganic source of nutrients (Punitha Premanantharajan and Komathy Prapagar, 2013). For maintaining soil fertility poultry manure occupied a place as it is rich in nutrient then the other manures (Mohamad Ananullah et al., 2007).

Application of poultry manure increases soil organic matter content, total-N, available-P, exchangeable cations ( $\mathrm{Ca}, \mathrm{Mg}$ and $\mathrm{K}$ ), CEC and percent base saturation (Adeleye, 2007).

\section{Materials and Methods}

The experiment was conducted during Kharif season 2016 on crop research farm of Department of Soil Science and Agricultural Chemistry, Naini Agricultural Institute, Allahabad. The area is situated on the south of Allahabad on the right side of the river Yamuna on the South of Rewa road at a distance of about $6 \mathrm{~km}$ from Allahabad city. It is situated at 25024'23" N latitude, 81050'38" E longitude and at the altitude of 98 meter above the sea level (MSL).

The treatment consists of poultry manure and PSB Culture with different levels of Phosphorus. $\mathrm{T}_{1}[\mathrm{P} \quad 0 \%+$ uninoculated (control)], T2 [P $0 \%+$ poultry manure], $\mathrm{T}_{3}[\mathrm{P}$ $0 \%+\mathrm{PSB}$ culture $], \mathrm{T}_{4}[\mathrm{P} 50 \%+$ un inoculated], $\mathrm{T}_{5}$ [P 50\% + poultry manure]. $\mathrm{T}_{6}$
[P 50\% + PSB culture], T7 [P 100\% + uninoculated], $\mathrm{T}_{8}$ [P 100\% + poultry manure], $\mathrm{T}_{9}[\mathrm{P} 100 \%+\mathrm{PSB}$ culture]. The trial was laid out in a randomized block design with three replications; plot size was $2 \times 2 \mathrm{~m}$ for crop seed rate is $20 \mathrm{~kg} \mathrm{ha}^{-1}$ (Vigna mungo L). Applies the recommended dose of nitrogen, potassium, poultry manure and PSB culture and phosphorus in different levels with source of urea, MOP, and SSP respectively, Basal dose of fertilizer was applied and poultry manure applies in respective plots according to treatment and PSB culture applies as seed treatment according to treatment.

All the agronomic practices were carried out uniformly to raise the crop. Soil samples were collected from the soil $0-15 \mathrm{~cm}$ depth, air dried kept in an oven at $105^{\circ} \mathrm{C}$ for $48 \mathrm{hrs}$ for drying, pass through $2 \mathrm{~mm}$ sieve, soils were analysis by using standard procedures as described for bulk density $\left(\mathrm{Mg} \mathrm{m}^{-3}\right)$, particle density $\left(\mathrm{Mg} \mathrm{m}^{-3}\right)$, Pore space $(\%)$ and Water holding capacity (\%) (Muthuaval et al., 1992), pH 1:2 (s/w) (Jackson, 1958), EC $\left(\mathrm{dSm}^{-1}\right)$ (Wilcox, 1950), organic carbon (\%) (Walkley, 1947), available Nitrogen $\mathrm{kg} \mathrm{ha}^{-1}$ (Sobbiah and Asija, 1956), phosphorus kg ha${ }^{1}$ (Olsen et al., 1954) and potassium $\mathrm{kg} \mathrm{ha}^{-1}$ (Tooth and Princr, 1949).

\section{Results and Discussion}

All parameters found significant accept Pore space (\%). Physical properties viz., bulk density $\left(\mathrm{Mg} \mathrm{m}^{-3}\right)$, particle density $\left(\mathrm{Mg} \mathrm{m}^{-3}\right)$, and Water holding capacity (\%) was recorded as 1.30, 2.85, 52.94, 64.69 and chemical properties viz., pH, EC, organic carbon (\%), available nitrogen $\left(\mathrm{kg} \mathrm{ha}{ }^{-1}\right)$, available phosphorus $\left(\mathrm{kg} \mathrm{ha}^{-1}\right)$ and potassium $\left(\mathrm{kg} \mathrm{ha}^{-1}\right)$, was recorded as 7.19, 0.19, 0.79, 263.01, $23.89,132.57$ respectively in the treatment was significantly higher as compared to other treatment combination. 
Microbial inoculation not only increased the nutritional assimilation (total $\mathrm{N}, \mathrm{P}$ and $\mathrm{K}$ ) of plants, but also improved soil properties. In this study, soil was tested before sowing and after harvest of black gram crop for residual NPK content.

Available P content increased significantly in inoculated soil then uninoculated content. It may be due to reason that as the phosphorus solubilizers increased the availability thereby improved phosphorus concentration in soil (Raut et al., 2000).

Available $\mathrm{N}$ content significantly increased may be due to fact that legumes contribute to the total pool of nitrogen in the soil as observed by Ahmad et al., (2001).

Table.1 Effect of poultry manure and PSB culture with different levels of phosphorus on physical properties of soil before sowing and after harvest of black gram crop

\begin{tabular}{|c|c|c|c|c|}
\hline Treatment & $\begin{array}{c}\text { Bulk density }(\mathrm{Mg} \\
\left.\mathrm{m}^{-3}\right)\end{array}$ & $\begin{array}{c}\text { Particle density (Mg } \\
\left.\mathbf{m}^{-3}\right)\end{array}$ & Pore space (\%) & $\begin{array}{c}\text { Water holding } \\
\text { capacity }(\%)\end{array}$ \\
\hline $\begin{array}{l}\text { Before sowing } \rightarrow \\
\text { After harvest } \downarrow\end{array}$ & 1.23 & 2.87 & 48.33 & 54.89 \\
\hline $\mathbf{T}_{1}$ & 1.30 & 2.22 & 51.96 & 59.11 \\
\hline $\mathbf{T}_{2}$ & 1.17 & 2.41 & 52.08 & 62.24 \\
\hline $\mathbf{T}_{3}$ & 1.29 & 2.41 & 49.01 & 58.56 \\
\hline $\mathbf{T}_{4}$ & 1.25 & 2.22 & 52.94 & 58.52 \\
\hline $\mathbf{T}_{5}$ & 1.17 & 2.62 & 49.03 & 62.27 \\
\hline $\mathbf{T}_{6}$ & 1.22 & 2.41 & 50.00 & 57.68 \\
\hline $\mathbf{T}_{7}$ & 1.22 & 2.73 & 44.97 & 61.07 \\
\hline $\mathbf{T}_{8}$ & 1.15 & 2.85 & 45.69 & 64.49 \\
\hline $\mathbf{T}_{9}$ & 1.21 & 2.50 & 49.02 & 61.32 \\
\hline S. Em ( $( \pm)$ & 0.03 & 0.11 & 2.67 & 1.08 \\
\hline C. D. at 5\% & 0.06 & 0.24 & 5.67 & 2.29 \\
\hline
\end{tabular}

Table.2 Effect of poultry manure and PSB culture with different levels of phosphorus on Chemical properties of soil before sowing and after harvest of black gram crop

\begin{tabular}{|c|c|c|c|c|c|c|}
\hline Treatment & $\begin{array}{c}\text { pH } \\
(1: 2)\end{array}$ & $\begin{array}{c}\mathrm{EC}\left(\mathrm{dSm}_{1}^{-}\right. \\
\mathbf{1}^{-}\end{array}$ & O.C (\%) & $\begin{array}{c}\text { Nitrogen }(\mathrm{kg} \\
\left.\mathrm{ha}^{-1}\right)\end{array}$ & $\begin{array}{l}\text { Phosphorus } \\
\left.\text { (kg ha }^{-1}\right)\end{array}$ & $\begin{array}{c}\text { Potassium } \\
\left(\mathrm{kg} \mathrm{ha}^{-1}\right)\end{array}$ \\
\hline $\begin{array}{l}\text { Before sowing } \rightarrow \\
\text { After harvest } \downarrow\end{array}$ & 7.33 & 0.24 & 0.48 & 216.91 & 12.63 & 120.54 \\
\hline$T_{1}$ & 7.13 & 0.14 & 0.56 & 214.81 & 13.26 & 118.55 \\
\hline $\mathbf{T}_{2}$ & 7.04 & 0.14 & 0.61 & 232.62 & 14.63 & 126.10 \\
\hline $\mathbf{T}_{3}$ & 7.05 & 0.14 & 0.51 & 208.52 & 16.69 & 120.71 \\
\hline $\mathbf{T}_{4}$ & 7.15 & 0.14 & 0.64 & 222.14 & 13.60 & 122.33 \\
\hline $\mathbf{T}_{5}$ & 7.06 & 0.16 & 0.72 & 251.49 & 17.72 & 131.32 \\
\hline$T_{6}$ & 7.15 & 0.16 & 0.55 & 221.09 & 20.80 & 125.02 \\
\hline $\mathbf{T}_{7}$ & 7.13 & 0.18 & 0.68 & 216.91 & 14.63 & 130.28 \\
\hline $\mathbf{T}_{8}$ & 7.02 & 0.15 & 0.69 & 263.01 & 20.46 & 132.57 \\
\hline$T_{9}$ & 7.19 & 0.19 & 0.72 & 236.82 & 23.89 & 128.79 \\
\hline S. Em ( $( \pm)$ & 0.02 & 0.01 & 0.00 & 7.66 & 1.93 & 3.07 \\
\hline C. D. at $5 \%$ & 0.04 & 0.02 & 0.03 & 16.23 & 4.09 & 6.50 \\
\hline
\end{tabular}


Fig.1 Effect of poultry manure and PSB culture with different levels of phosphorus on bulk density, particle density, percent pore space and water holding capacity of soil after harvest of black gram crop

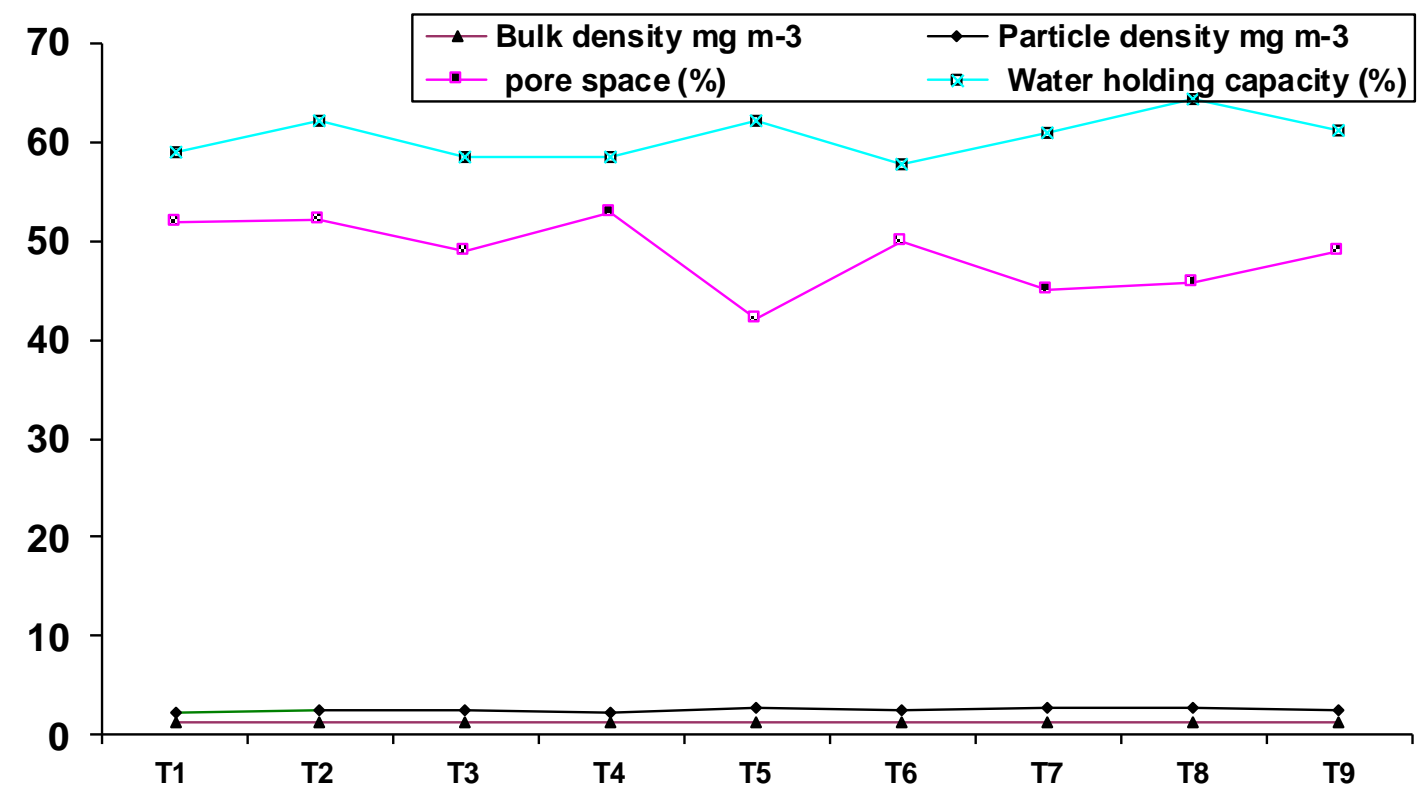

Fig.2 Effect of poultry manure and PSB culture with different levels of phosphorus on $\mathrm{pH}$, EC, and organic carbon of soil after harvest of black gram crop

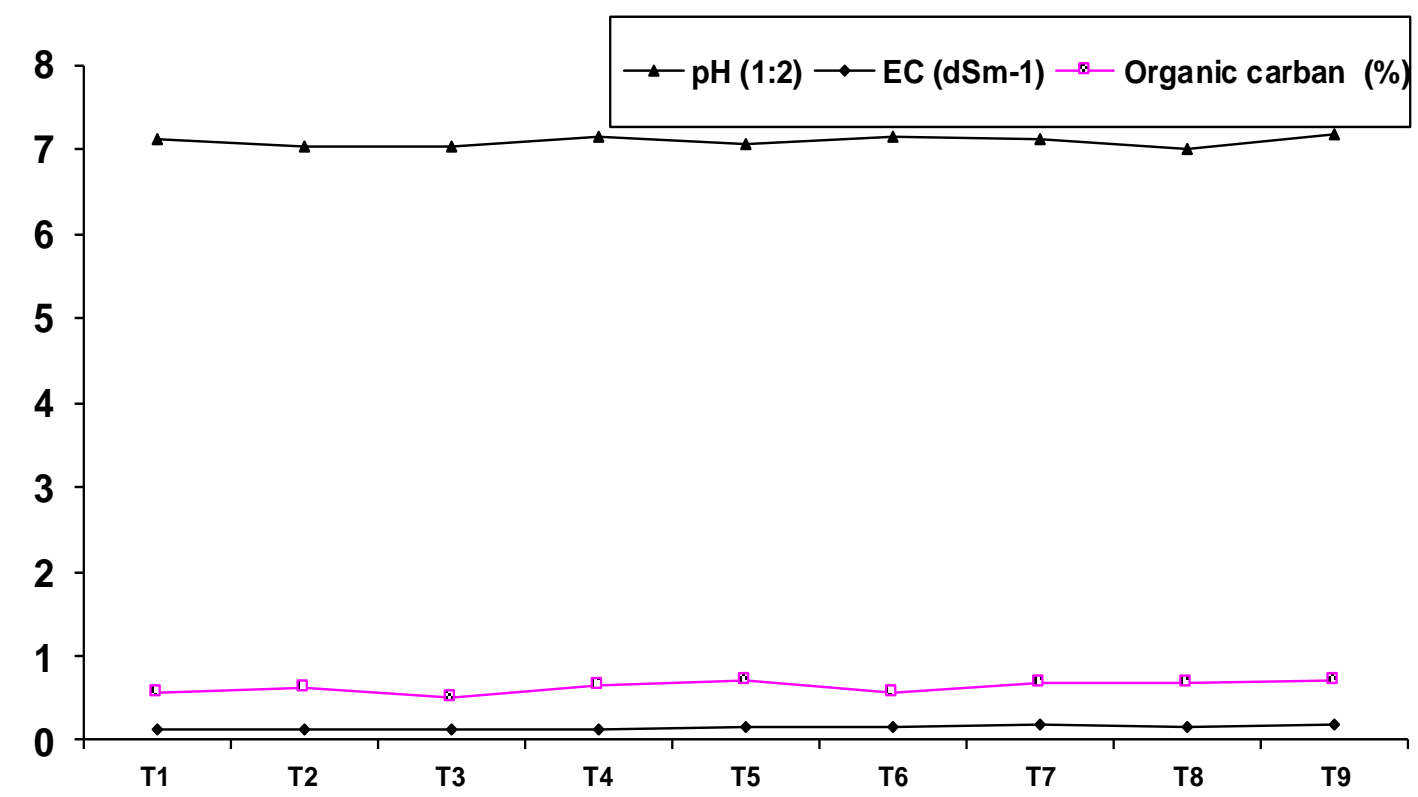


Fig.3 Effect of poultry manure and PSB culture with different levels of phosphorus on NPK in soil after harvest of black gram crop

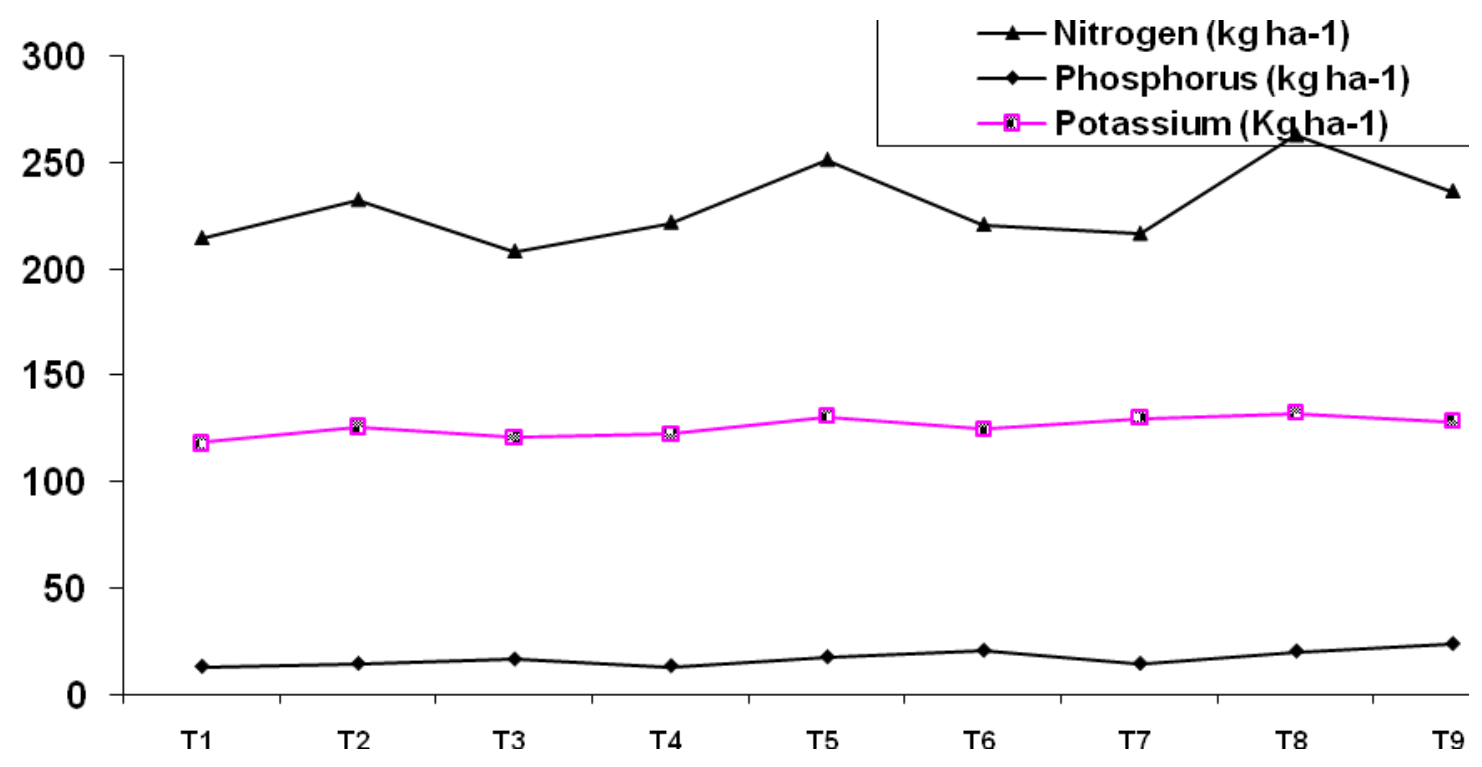

Poultry manure additions up to $50 \mathrm{t} \mathrm{ha}^{-1}$ improved soil organic matter total $\mathrm{N}$ and available $\mathrm{P}$ as well as improved soil physical properties as indicated by reduction in soil bulk density and increased in soil moisture content (Ewulo et al., 2008).

The results in given tables 1 and 2 indicate some of the important parameter on physicochemical properties of soil on black gram crop different treatment of poultry manure and PSB culture with levels of phosphorus.

It may be concluded from trial that the different level of phosphorus with PSB culture in the experiment. Bulk density $(\mathrm{Mg}$ $\left.\mathrm{m}^{-3}\right)$, particle density $\left(\mathrm{Mg} \mathrm{m}^{-3}\right)$ Pore space $(\%)$, water holding capacity $(\%)$, organic carbon $(\%)$, available nitrogen $\left(\mathrm{kg} \mathrm{ha}^{-1}\right)$ and potassium $\left(\mathrm{kg} \mathrm{ha}^{-1}\right) \mathrm{T}_{8}(\mathrm{P} 100 \%+$ poultry manure) and $\mathrm{pH}, \mathrm{EC}\left(\mathrm{dSm}^{-1}\right)$ and available phosphorus $\left(\mathrm{kg} \mathrm{ha}^{-1}\right) \mathrm{T}_{9}(\mathrm{P} 100 \%+\mathrm{PSB}$ culture) was found to be the best for improvement of the physico-chemical properties of soil (Figs. 1-3).

\section{Acknowledgement}

Authors are sincerely thankful to Prof. (Dr.) Gautam Ghosh Dean, Naini Agricultural Institute Allahabad, for allowing and encouragement to carry out the research work at Sam Higginbottom University of Agriculture, Technology and Sciences, Allahabad.

\section{References}

Adeleye EO, Ayeni LS and Ojeniyi SO. 2010. Effect of poultry manure on soil physiochemical properties, leaf nutrient contents and yield of yam (Dioscorea rotudata) on alfisol in southwestern Nigeria. Journal of American science 6(10)

Ahmad T, Hefeez FY, Mehmood T and Malik KA. 2001. Residual effect of Nitrogen fixed by mungbean (Vigna mungo) on subsequent rice and white crop. Austration J. Experimental agriculture, $41 ; 245-248$. 
Black CA. 1965. Method of soil Analysis. Vol.1. Amer. Soc. Agron. Madison. Wisoosin, UDA.

Ewulo BS, OJeniyi SO and akanni DA. 2008. Effect of poultry manure on selected soil physical and chemical properties, growth, yield and nutrient status of tomato. African journal of agriculture research vol.3(9), pp. 612-616

Jackson ML. 1958. Soil chemical analysis. prentice hall of India private limited New delhi (1973)

Kudam swati, Kalegore NK, Patil sneha. 2014. effect of Phosphorus, Vermicompost and PSB on seed yield, yield attributes and economics of black gram (Vigna mungo L.). IJIRD. Vol 3, Issue 9.

Madane Ananda Jagannath, Chavan MG, Rajemahadik VA and Singh JK. 2014. Response of summer black gram (Vigna mungo) varieties to phosphorus levels under lateritic soil of Konkan. ISSN: volume no.3 issue no.3, pp-259-262

Mir AH, Lal SB, Salmani M, Abib M and Khan I.2013. growth yield and nutrient content of black gram (Vigna mungo) as influenced by levels of phosphorus, Sulphur and phosphorus solubilizing bacteria. SAARC J. Agri., 11(1): 1-6

Mohamad Amanullah, Somasundaram M, Vyapari E and Sathyamoorthi K. 2007. Poultry manure to crops-A review. Agric. Rev. 28(3). 216-222

Muthuaval PC, Udayasoorian R, Natesan PP and Ramaswami. 1992. Introduction to soil Analysis, Tamilnadu Agriculture University, Coimbtore- 641002.
Olsen SR, Cole CV and Watnahe FS. 1954. Estimation of available phosphorus in soil by extraction with Sodium bicarbonate U.S. Dept. Agro. core. 939.

Premanantharajah P and Prapagar K. 2013. Effect of poultry manure as partial substitute for $\mathrm{P}$ and $\mathrm{S}$ on the yield and quality of groundnut. SEUSL; 6-7 July 2013.

Raut RF, Hamid Abdul, Hadole SS and Jeughale GS. 2000. Effect of irrigation and sulphur on concentration, uptake and availability of nitrogen, sulphur and phosphorus in mustard. Jounal of Soils and Crops. 10; 145-148.

Selvakumar G, Reetha S and Thamizhiniyan P. 2012. Response of biofertilizer on growth, yield attributes and associated protein profiling changes of black gram (Vigna mungo L. hepper). World applied science journal 16 (10) : 1368-1374

Sobbiah BV and Asija CL. 1956. A rapid procedure for the estimation of available nitrogen in soils. Current Sci. 25: 258260.

Tooth SJ, and Princr AL. 1949. Estimation of cation exchange capacity and Exchangeable $\mathrm{Ca}, \mathrm{K}$. and Na. content of soil by flame photometer technique soil Sci. 67: 439-445.

Walkley A. 1947. Critical Examination of rapid method for determining organic carbon in soil. Effect of variation in digestion condition and of inorganic soil constituents, soil sci. 632-251.

Wilcox LV. 1950. Electrical conductivity, Am. Water Assoc. J., 42: 775-776.

\section{How to cite this article:}

Raisen Pal, N. Swaroop, Arun A. David and Thomas, T. 2017. Effect of Poultry Manure and PSB Culture in Conjunction with Different Levels of Phosphorus on Physico-Chemical Properties of Soil of Black Gram (Vigna mungo L.). Int.J.Curr.Microbiol.App.Sci. 6(7): 128133. doi: https://doi.org/10.20546/ijemas.2017.607.015 